\title{
Adiós, Robinson CRUSOe
}

\author{
Iveth Luna Flores
}

Me escribes a las 2 de la mañana, me escribes a las 6 , me alientas a que sea feliz, aseguras que tú estás bien, respondes preguntas que yo jamás hice, me envías canciones, me cuentas sobre lo que comiste, aseguras de nuevo que estás bien.

Me escribes: se me fue mi piar, me escribes: se me fue mi piedra.

Corriges: se me fue mi pilar.

Te disculpas: se me fue mi padre. 
No hubo carroza fúnebre, no hubo gente de negro, en ese lugar mantienen al cuerpo dos metros bajo tierra por 37.50 pesos al mes.

Dos coronas medio marchitas y algunos hombres ebrios.

Así son las cosas, ¿ves?

Así son las cosas, ¿a poco no lo ves?

Papá era el único que iba de negro, estaba tambaleándose en medio del cementerio, dijo que quería ir a caminar, gritó que lo dejaran ir a caminar, pero ninguno de nosotros lo estaba deteniendo. 
De aquellos años solo un libro viejo de Robinson Crusoe y una botella de agua de colonia

Flor de naranja en su buró;

sus chanclas, las camisas nejas y el olor que despedía su cama individual, que no era suya, sino de mi hermano mayor.

De los recientes daños solo se cayó, se calló y como bolsita de ziploc jamás abierta todo lo de adentro se pudrió. 
Lo vi apretar su playera negra con las manos, lo vi apretar los párpados y resoplar hondo.

No me acerqué a ver el féretro del abuelo.

Abuelo: no me atreví a ver tu cuerpo putrefacto por respeto a todo el tiempo en que no te vi.

Un tanque que ha pasado años acumulando agua, seguro ha acumulado lama y es muy probable que ya haya anidado larvas.

No voy a desatar los nudos que tienes en la garganta, papá, no lo voy a hacer por ti.

Abuelo: ¿ahora sí me vas a contar por qué conservabas ese libro de Robinson Crusoe? 
Se prohíbe su reproducción total o parcial por cualquier medio, incluido electrónico, sin permiso previo y por escrito de los editores.

IVETH LUNA FLORES

Me dijo que lo amenazó:

Si no te levantas, te voy a llevar a un asilo.

Días de no comer, de enojarse, de cagarse en los pantalones, de no beber agua.

No necesitaron practicarle autopsia.

Días de venganza, adiós, Robinson Crusoe. 